\title{
Prospects of building an agenda for technology transfer policy advocacy in Brazil from international experience
}

\author{
Luiz Guilherme de Oliveira \\ Professor at the University of Brasilia, UnB.
}

\begin{abstract}
The process of developing technological skills, especially for late developing countries such as Brazil, is characterized by high cost and long maturation. The objective of this paper is to support the formulation of local policies related to the transfer of technology through compensation mechanisms, mainly technological, offset type. Although the offset mechanisms are not new in the field of technological public policies between countries, they have different forms of structuring that modify between countries and between sectors of the economy. The present study aims to focus on the offset policies in the defense sector, from selected countries (Sweden, Spain, United Kingdom, Italy, India and Canada) seeking to observe issues such as investment maturation period, focus, legal framework between others. From this it is sought to consider the best practices among selected countries.
\end{abstract}

Keywords: offset policy, national defense, technology transfer

\section{INTRODUCTION}

This paper seeks to describe and contextualize the issue of "offset policy" in Brazil. For this, the strategic importance of the technological agenda for the defense sector in the countries, especially the countries of late development and of important economic importance, stands out. Two important and complementary aspects of the Brazilian defense industry should be highlighted: i) the role of the defense industry in Brazil, as a highlight of the industry's export potential, ii) the need for technological autonomy for the defense sector, considering national defense agenda. In this context, the history and the trajectory of the defense industry in the country and the use of the offset policy, highlighting the aeronautical sector, as a mechanism of technological induction are verified.

\section{METHODOLOGY}

The proposal for the construction of this work was structured in four parts. Initially we looked for a historical perspective of the production numbers of the defense sector in Brazil and in the world. The sources and data are several: (i) secondary data from the work of researchers in Brazil, the Stockholm International Peace Research Institute (SIPRI) and Columbia University's Institute of War and Peace (SIWPS); ii) Primary data from the Ministry of Science, Technology and Innovation (MCTI), Ministry of Development Industry and Commerce (MDCI) and Ministry of Defense (MD).

In the next section, the international experience, the objective is to observe how some selected countries deal with the "offset policy" agenda. For the selection of countries, issues related to the importance of countries in the context of active technology transfer will be considered.

Having exhausted the observation of the selected countries, in the third stage a matrix was constructed to compare the "offset policies" adopted by these countries. The variables were selected after the data collection phase. 
Finally, in the last section, the conclusions of the study are drawn which indicate the need to construct a policy of "technological offset" for the defense area that can make feasible the increase of capacity, and competence, technique of small and medium enterprises, as well as serve as a mechanism of induction in the relations between University and Company. In this sense, it is possible to observe that some countries adopt this option without prejudice to the construction of industrial and commercial policies.

\section{INTERNATIONAL DEFENSE MARKET}

International trade in defense equipment peaked in 1982, with $\$ 46.4$ billion traded. With the decline of the Soviet Union and the end of the Cold War, there was a significant reduction in defense investments, with exports dropping to $\$ 17.9$ billion in 2002 . Since then there has been a re-stocking of the military in several countries, with exports reaching a value of $\$ 30$ billion in 2011, an increase of 55.75\% compared to 2002 (SIPRI, 2008).

It is important to highlight that the practice of offset extrapolates the standard relations of international cooperation of science and technology that by themselves have very peculiar and complex characteristics (Silva, 2007). A characteristic of defense products and equipment is that they are not restricted to a specific sector, so they can not be easily identified from classifications normally used in international trade, such as the Harmonized System Code or the Mercosur Common Nomenclature (NCM).

Historically, it is possible to see that Brazil occupied a prominent position among the countries that produce defense equipment. Currently, the table shows that the export of arms and ammunition jumped from US\$60 to US\$ 292 million from 1997 to 2011, with a growth of 274.13\%, maintaining a significant positive balance (DAGNINO and CAMPOS FILHO, 2007) . Radar equipment was the one that represented the greatest impact on imports, driven by the Amazon Surveillance System (SIVAM). For other equipment the numbers are relatively low, both in import and export.

\section{DISCIPLINES OF THE WORLD TRADE ORGANIZATION CONCERNING OFFSET}

The World Trade Organization (WTO) in Article XVI of the Government Procurement Agreement (GPA) prohibits, as a general rule, the use of offsets. The Agreement, however, opens two important exceptions to this prohibition, authorizing the practice of offset in the following cases:

I. Special and differential treatment for developing countries. According to Article XVI: 2 of the GCA, developing countries may negotiate conditions for the use of offsets at the time of their access to the Agreement, ensuring that they will only be used as qua lification to participate in the procurement process, and not as a concession criterio $\mathrm{n}$ of contracts;

II. Government purchases related to national security, or for defense purposes, as spell ed out in Article XXIII: 1.

The international community's understanding of permitting under the ACG's offset practice for the defense industry is common. It is important to point out, however, that the ACG, despite emanating from the Uruguay Round, is a plurilateral agreement (not part of the "singleundertaking" of the Round), and Brazil is not a signatory to the Agreement.

\section{"Offering" offset policy - The International Initiative to limit the adverse effects of offsetting on defense purchases}

In 2004, the US government established an inter-ministerial working group to initiate a process of dialogue with other countries and international organizations to discuss the adverse 
impacts of offset on defense purchases. The main objectives of this initiative were: (i) to promote a global understanding of how different types of offset impact the industrial base; (ii) encourage the development of global principles to limit the negative impacts of offsets; and (iii) encourage countries to give maximum flexibility in meeting offset requirements.

\section{United States and Offset}

The US Government's antitrust policy considers offset to be an "economically inefficient and trade-distorting" practice, and prohibits any US government agency from directly encouraging or engaging US firms in any offset arrangement in connection with the sale of defense articles or services to governments of other countries. However, in practice, US firms argue that in reality the business market competing in international defense processes, offsets are generally required to realize the sale (Neuman, 2010).

According to data from the "16th Report on Offset in Defense Trade" prepared by the United States Department of Commerce during the period 1993 to 2010, 52 US companies reported having participated in 763 offset contracts related to the export of goods and services defense, worth US \$ 111 billion, with 47 countries. The offset agreements associated with the contracts accounted for 78 billion.

\begin{tabular}{|c|c|c|c|c|c|c|}
\hline \multicolumn{7}{|c|}{ Table 2-1: Summary of Defense Export Sale Contract Values with Related Offset Agreements, $1993-2010$} \\
\hline Year & $\begin{array}{c}\text { Contract Value } \\
(\$ \text { millions })\end{array}$ & $\begin{array}{c}\text { Offset Agreement } \\
\text { Value } \\
(\$ \text { millions })\end{array}$ & $\begin{array}{l}\text { Percent of Offset } \\
\text { Agreement to } \\
\text { Contract Value }\end{array}$ & $\begin{array}{l}\text { U.S. Firms } \\
\text { (Number) }\end{array}$ & $\begin{array}{c}\text { Agreements } \\
\text { (Number) }\end{array}$ & $\begin{array}{l}\text { Countries } \\
\text { (Number) }\end{array}$ \\
\hline 1993 & $\$ 13,935.00$ & $\$ 4,784.43$ & $34.33 \%$ & 17 & 28 & 16 \\
\hline 1994 & $\$ 4,792.42$ & $\$ 2,048.72$ & $42.75 \%$ & 18 & 49 & 20 \\
\hline 1995 & $\$ 7,529.92$ & $\$ 6,102.58$ & $81.04 \%$ & 20 & 47 & 18 \\
\hline 1996 & $\$ 3,119.67$ & $\$ 2,431.62$ & $77.94 \%$ & 16 & 53 & 19 \\
\hline 1997 & $\$ 5,925.47$ & $\$ 3,825.53$ & $64.56 \%$ & 15 & 60 & 20 \\
\hline 1998 & $\$ 3,029.20$ & $\$ 1,768.15$ & $58.37 \%$ & 12 & 41 & 17 \\
\hline 1999 & $\$ 5,656.62$ & $\$ 3,456.89$ & $61.11 \%$ & 10 & 45 & 11 \\
\hline 2000 & $\$ 6,576.21$ & $\$ 5,704.81$ & $86.75 \%$ & 10 & 43 & 16 \\
\hline 2001 & $\$ 7,116.00$ & $\$ 5549.55$ & $77.99 \%$ & 12 & 35 & 13 \\
\hline 2002 & $\$ 7,406.23$ & $\$ 6,094.81$ & $82.29 \%$ & 12 & 41 & 17 \\
\hline 2003 & $\$ 7,293.05$ & $\$ 9,110.44$ & $124.92 \%$ & 11 & 32 & 13 \\
\hline 2004 & $\$ 4,927.51$ & $\$ 4,329.69$ & $87.87 \%$ & 14 & 40 & 18 \\
\hline 2005 & $\$ 2,259.87$ & $\$ 1,464.13$ & $64.79 \%$ & 8 & 25 & 18 \\
\hline 2006 & $\$ 5,088.53$ & $\$ 3,573.91$ & $70.23 \%$ & 14 & 46 & 21 \\
\hline 2007 & $\$ 6,735.74$ & $\$ 5,437.57$ & $80.73 \%$ & 11 & 44 & 19 \\
\hline 2008 & $\$ 6,286.16$ & $\$ 3,664.43$ & $58.29 \%$ & 15 & 53 & 17 \\
\hline 2009 & $\$ 10,700.53$ & $\$ 6,696.44$ & $62.58 \%$ & 13 & 57 & 21 \\
\hline 2010 & $\$ 3,209.39$ & $\$ 2,038.48$ & $63.52 \%$ & 12 & 24 & 12 \\
\hline Total & $\$ 111,587.54$ & $\$ 78,082.20$ & $69.97 \%$ & 52 & 763 & 47 \\
\hline
\end{tabular}

\section{European Union and Offset}

In August 2011 a Directive on Government Procurement of Defense entered into force in the European Union. The directive aims to bring trade into the defense sector to the aegis of the European Union Agreement. Although the Directive does not explicitly use the term "offset", guides published by the EC attest that offsets would not be allowed on purchases made under the rules of the Directive. If a Member State wishes to impose offset obligations on the purchase of defense articles, it will have to invoke Article 346 of the Treaty on European Union (national security exception). It is considered that the entry into force of the Directive could potentially reduce the use of offset in Europe. 
In addition, the European Defense Agency (EDA) in 2009 established a "Code of Conduct for Offset", signed by all its members, except for Romania. This Code applies when a member invokes Article 346 of the Treaty on European Union, a situation in which the directive on government procurement of defense is no longer applied. According to the Code, offsets required or accepted by member states may not exceed the limit of the value of the contract (limit of 100\% for offset). In addition, it provides that offsets should have a lower weight in bidding bids (or used as subsidiary criteria in same-weight bids) to ensure that the purchase decision is based on the best available solution that brings greater economic benefits. Finally, the Code provides that Member States will allow international bidders to select their offset partners or recipients within the purchasing country, providing fair and open competition within supply chains. Although the Code is non-binding, according to EDA its members generally adopt the provisions established by the Agency.

\section{"Claimant" offset policy}

The analysis of the offset policy was structured based on the verification of the practices adopted by the selected countries (see Tables 1 to 3). The variables considered are organized as follows: Table 1 - legal basis, responsible authority, objectives and period of execution; Table 2 - requirements, multipliers, direct / indirect offset, eligible activities; Table 3 - eligible sectors, receiver selection, monitoring.

\section{Table 1}

With regard to the legal basis, it is possible to verify that all selected countries, with the exception of Italy, have a specific legal framework for the agenda related to offset. In some cases (eg Canada and the United Kingdom) the legal framework seeks to converge with the country's industrial policy. It is noteworthy that, with the exception of Canada, the policymaking authority of all the countries mentioned, linking their offset policies with their Defense Ministries, sometimes acting in convergence with other departments linked to industrial and technological policies, as an example it is possible to highlight the UK in the relationship between Ministry of Defense and Department of Trade and Investment. The proximity between defense ministries and industrial development agencies is clear from the objectives described by policies that focus primarily on strengthening the local defense industry through access to technology or access to new external markets. For the duration of the contract, in most cases, with the exception of India, the duration of the contract is respected. 
Table 1 - Comparative Offset Policies - selected countries (part 1)

\begin{tabular}{|c|c|c|c|c|c|c|}
\hline & Canada & Spain & India & Italy & $\begin{array}{c}\text { United } \\
\text { Kingdom } \\
\end{array}$ & Sweden \\
\hline Legal base & $\begin{array}{l}\text { Industrial } \\
\text { Policy and } \\
\text { Regional } \\
\text { Benefits for } \\
\text { Large Crown } \\
\text { Projects. }\end{array}$ & $\begin{array}{l}\text { Directive of } \\
\text { the } \\
\text { Secretary of } \\
\text { State for } \\
\text { Defense }\end{array}$ & $\begin{array}{l}\text { Revised } \\
\text { Defense } \\
\text { Offset } \\
\text { Guidelines, } \\
\text { published in- } \\
2011\end{array}$ & $\begin{array}{l}\text { There is no } \\
\text { formal offset } \\
\text { policy. } \\
\text { Internal } \\
\text { directives of } \\
\text { the General } \\
\text { Secretariat of } \\
\text { Defense. } \\
\text { Offsets } \\
\text { applied to } \\
\text { each bid on a } \\
\text { case-by-case } \\
\text { basis. }\end{array}$ & $\begin{array}{l}\text { Industry } \\
\text { Participation } \\
\text { Policy (2003). }\end{array}$ & $\begin{array}{l}\text { Government } \\
\text { Procurement } \\
\text { Law; Industrial } \\
\text { Participation } \\
\text { Program } \\
\text { (1999). }\end{array}$ \\
\hline $\begin{array}{l}\text { Responsible } \\
\text { Authority }\end{array}$ & $\begin{array}{l}\text { Ministry of } \\
\text { Industry } \\
\text { (Industry } \\
\text { Canada) } \\
\text { together with } \\
\text { regional } \\
\text { development } \\
\text { agencies }\end{array}$ & $\begin{array}{l}\text { Ministry of } \\
\text { Defense } \\
\text { (National } \\
\text { Armaments } \\
\text { Director) } \\
\text { with the } \\
\text { support of } \\
\text { the } \\
\text { Industrial } \\
\text { Cooperation } \\
\text { Agency. }\end{array}$ & $\begin{array}{l}\text { Ministry of } \\
\text { Defense - } \\
\text { Defense } \\
\text { Offsets } \\
\text { Management } \\
\text { Wing and } \\
\text { Acquisition } \\
\text { Wing }\end{array}$ & $\begin{array}{l}\text { Ministry of } \\
\text { Defense } \\
\text { (National } \\
\text { Director of } \\
\text { Armaments) }\end{array}$ & $\begin{array}{l}\text { Ministry of } \\
\text { Defense } \\
\text { (responsible } \\
\text { for policy) and } \\
\text { Department of } \\
\text { Trade and } \\
\text { Investment. }\end{array}$ & $\begin{array}{l}\text { Ministry of } \\
\text { Defense (FMV). } \\
\text { The Ministry is } \\
\text { obliged to } \\
\text { consult the } \\
\text { Armed Forces to } \\
\text { decide on the } \\
\text { application of the } \\
\text { offset in specific } \\
\text { defense bidding } \\
\text { processes. }\end{array}$ \\
\hline Goals & $\begin{array}{l}\text { Long-term } \\
\text { industrial } \\
\text { development; } \\
\text { small business } \\
\text { development; } \\
\text { regional } \\
\text { development }\end{array}$ & $\begin{array}{l}\text { Develop an } \\
\text { industrial } \\
\text { base of } \\
\text { competitive } \\
\text { defense; } \\
\text { Encourage } \\
\text { and } \\
\text { consolidate } \\
\text { national } \\
\text { security of } \\
\text { supply and } \\
\text { the entire } \\
\text { life cycle. }\end{array}$ & $\begin{array}{l}\text { Develop the } \\
\text { Indian } \\
\text { defense } \\
\text { industry by } \\
\text { (i) } \\
\text { encouraging } \\
\text { business } \\
\text { development; } \\
\text { (ii) increased } \\
\text { research and } \\
\text { development } \\
\text { capacity; (iii) } \\
\text { encourage } \\
\text { the } \\
\text { development } \\
\text { of sectors } \\
\text { such as the } \\
\text { civil } \\
\text { aerospace } \\
\text { sector and } \\
\text { the internal } \\
\text { security } \\
\text { sector. }\end{array}$ & $\begin{array}{l}\text { Maintain and } \\
\text { strengthen } \\
\text { the capacity, } \\
\text { knowledge } \\
\text { and export } \\
\text { potential of } \\
\text { the Italian } \\
\text { defense } \\
\text { industrial } \\
\text { base. }\end{array}$ & $\begin{array}{l}\text { Encourage the } \\
\text { creation of } \\
\text { work and } \\
\text { business } \\
\text { opportunities } \\
\text { for UK } \\
\text { companies } \\
\text { and ensure } \\
\text { their access to } \\
\text { external } \\
\text { markets } \\
\text { through the } \\
\text { establishment } \\
\text { of long-term } \\
\text { partnerships } \\
\text { with foreign } \\
\text { companies. }\end{array}$ & $\begin{array}{l}\text { Support the } \\
\text { long-term } \\
\text { protection of } \\
\text { Sweden's basic } \\
\text { defense and } \\
\text { security } \\
\text { interests. } \\
\text { Ensure the } \\
\text { participation of } \\
\text { the domestic } \\
\text { manufacturing } \\
\text { industry. } \\
\text { Promote the } \\
\text { transfer of } \\
\text { advanced } \\
\text { technologies to } \\
\text { the defense } \\
\text { industry. } \\
\text { Increase } \\
\text { exports of } \\
\text { Swedish } \\
\text { defense-related } \\
\text { products, } \\
\text { systems and } \\
\text { advanced } \\
\text { technologies. }\end{array}$ \\
\hline $\begin{array}{l}\text { Period of } \\
\text { execution }\end{array}$ & $\begin{array}{l}\text { Usually the } \\
\text { contract } \\
\text { period. }\end{array}$ & $\begin{array}{l}\text { Usually the } \\
\text { contract } \\
\text { period. }\end{array}$ & $\begin{array}{l}\text { It may be } \\
\text { extended for } \\
\text { up to two } \\
\text { years after } \\
\text { completion } \\
\text { of the main } \\
\text { contract. }\end{array}$ & $\begin{array}{l}\text { Negotiated } \\
\text { case by case }\end{array}$ & $\begin{array}{l}\text { Usually the } \\
\text { contract } \\
\text { period. }\end{array}$ & $\begin{array}{l}\text { Usually the } \\
\text { contract } \\
\text { period. }\end{array}$ \\
\hline
\end{tabular}

\section{Source: Author's elaboration}




\section{Table 2}

When checking the requirements it is possible to verify that there is a variation of $30 \%$ to $100 \%$ of the contract, in some cases (Canada and Spain) space is opened to reduce these percentages. In the issue of multipliers there is a greater diversity of positions, Canada directs the action in the relations between University and Research Institutes with a ceiling of 5\%. Spain, on the other hand, generally does not use it, India and Italy, in turn, take a more aggressive stance. Italy focuses on three aspects: (i) technology already possessed by the domestic industry, (ii) technology partially owned by the domestic industry, (iii) technology is entirely new. The United Kingdom does not consider the issue. Sweden, in turn, seeks to look at issues that focus on the need for strengths and in the promotion of small and medium-sized enterprises and R \& D activities. Regarding the issue of offset, direct and indirect, there is no divergence since all the countries selected consider its adoption. In the eligible activities it is verified that, in general, they are considered co production, technical assistance, marketing and $\mathrm{R} \& \mathrm{D}$ activities. Attention is again drawn to the case of Sweden which considers transfer of technology and know-how, cooperation / collaboration in technology and R \& D, purchase of defense products and services, investments that enhance the competitiveness of the defense industry, collaborative activities for greater access to markets for Swedish products. 
Table 2 - Comparative Offset Policies - selected countries (part 2)

\begin{tabular}{|c|c|c|c|c|c|c|}
\hline & Canada & Spain & India & Italy & $\begin{array}{c}\text { United } \\
\text { Kingdom }\end{array}$ & Sweden \\
\hline Requirements & $\begin{array}{l}\text { Normally } \\
100 \% \text { of the } \\
\text { value of the } \\
\text { contract; only } \\
\text { the value of } \\
\text { Canadian } \\
\text { content is } \\
\text { computed; } \\
\text { obligatorily } \\
\text { new } \\
\text { economic } \\
\text { activities; } \\
\text { regional } \\
\text { distribution } \\
\text { of benefits is } \\
\text { important; } \\
\text { causality } \\
\text { must be } \\
\text { proven. }\end{array}$ & $\begin{array}{l}\text { Generally } \\
100 \% \text { of the } \\
\text { contract value. } \\
\text { A reduction can } \\
\text { be negotiated. }\end{array}$ & $\begin{array}{l}\text { Usually } 30 \% \\
\text { of the } \\
\text { contract } \\
\text { value. The } \\
\text { Defense } \\
\text { Acquisition } \\
\text { Council may } \\
\text { establish } \\
\text { higher } \\
\text { standards or } \\
\text { accept the } \\
\text { non- } \\
\text { application of } \\
\text { offset in } \\
\text { special cases. }\end{array}$ & $\begin{array}{l}\text { Determined } \\
\text { by } \\
\text { negotiation, } \\
\text { rotating } \\
\text { around } 75 \% \\
\text { to } 100 \% \text { of } \\
\text { the contract } \\
\text { value. }\end{array}$ & $\begin{array}{l}\text { There is no } \\
\text { pre- } \\
\text { established } \\
\text { percentage, } \\
\text { but up to } \\
100 \% \text { of the } \\
\text { contract } \\
\text { value. } \\
\text { Bidders } \\
\text { proposes the } \\
\text { level that will } \\
\text { be } \\
\text { negotiated. }\end{array}$ & $\begin{array}{l}\text { Minimum of } \\
100 \% \text { of the } \\
\text { contract } \\
\text { value. Offsets } \\
\text { are not } \\
\text { required from } \\
\text { companies in } \\
\text { countries that } \\
\text { do not have } \\
\text { an offset } \\
\text { policy. }\end{array}$ \\
\hline Multipliers & $\begin{array}{l}\text { Usually used } \\
\text { only for offset } \\
\text { activities } \\
\text { involving } \\
\text { Canadian } \\
\text { universities } \\
\text { or research } \\
\text { institutes, up } \\
\text { to a } \\
\text { maximum of } \\
5 \% \text {. }\end{array}$ & $\begin{array}{l}\text { They are } \\
\text { generally not } \\
\text { used. }\end{array}$ & $\begin{array}{l}\text { Multiplier of } \\
1.5 \text { is allowed } \\
\text { in cases } \\
\text { where micro, } \\
\text { small and } \\
\text { medium- } \\
\text { sized } \\
\text { companies } \\
\text { are Indian } \\
\text { offset } \\
\text { partners. }\end{array}$ & $\begin{array}{l}\text { (a) } \\
\text { technology } \\
\text { already } \\
\text { owned by the } \\
\text { domestic } \\
\text { industry (1); } \\
\text { (b) } \\
\text { technology } \\
\text { partly owned } \\
\text { by the } \\
\text { domestic } \\
\text { industry (2); } \\
\text { c) technology } \\
\text { is totally new } \\
\text { (3) }\end{array}$ & none & $\begin{array}{l}\text { They are } \\
\text { usually not } \\
\text { applied. They } \\
\text { can be } \\
\text { considered for } \\
\text { R \& D } \\
\text { unrelated to } \\
\text { the contract, } \\
\text { which is } \\
\text { developed in } \\
\text { Sweden for the } \\
\text { participation of } \\
\text { small and } \\
\text { medium-sized } \\
\text { enterprises, } \\
\text { and in support } \\
\text { of priority } \\
\text { areas for the } \\
\text { Armed Forces. }\end{array}$ \\
\hline $\begin{array}{l}\text { Direct / } \\
\text { indirect }\end{array}$ & $\begin{array}{l}\text { Both } \\
\text { categories are } \\
\text { accepted, but } \\
\text { preference } \\
\text { for direct } \\
\text { offset }\end{array}$ & $\begin{array}{l}\text { Both categories } \\
\text { are accepted, } \\
\text { but there is } \\
\text { preference for } \\
\text { direct offset. } \\
\text { Required } \\
\text { proportion } \\
\text { varies from } \\
\text { contract to } \\
\text { contract. }\end{array}$ & $\begin{array}{l}\text { Both } \\
\text { categories are } \\
\text { accepted. }\end{array}$ & $\begin{array}{l}\text { Both } \\
\text { categories are } \\
\text { accepted. } \\
\text { There is a } \\
\text { preference } \\
\text { for direct } \\
\text { offset. }\end{array}$ & $\begin{array}{l}\text { Direct } \\
\text { benefits as } \\
\text { well as } \\
\text { indirect } \\
\text { intellectual } \\
\text { property are } \\
\text { acceptable. }\end{array}$ & $\begin{array}{l}\text { Both } \\
\text { categories are } \\
\text { accepted. }\end{array}$ \\
\hline $\begin{array}{l}\text { Eligible } \\
\text { activities }\end{array}$ & $\begin{array}{l}\text { Direct } \\
\text { participation } \\
\text { of Canadian } \\
\text { companies in } \\
\text { the } \\
\text { production } \\
\text { and support } \\
\text { of the } \\
\text { equipment } \\
\text { being bid. }\end{array}$ & $\begin{array}{l}\text { Coproduction } \\
\text { (licenses and } \\
\text { patents), } \\
\text { purchases of } \\
\text { domestic } \\
\text { products and } \\
\text { services; } \\
\text { collaboration } \\
\text { in R \& D; } \\
\text { provision of } \\
\text { equipment, } \\
\text { tools and }\end{array}$ & $\begin{array}{l}\text { a) Direct } \\
\text { purchase of } \\
\text { products or } \\
\text { services from } \\
\text { Indian } \\
\text { companies; b) } \\
\text { Foreign } \\
\text { direct } \\
\text { investment in } \\
\text { joint ventures } \\
\text { with Indian } \\
\text { companies. }\end{array}$ & $\begin{array}{l}\text { Participation } \\
\text { in the } \\
\text { development, } \\
\text { production } \\
\text { and } \\
\text { assistance of } \\
\text { the } \\
\text { equipment } \\
\text { being } \\
\text { purchased. } \\
\text { Transfer of } \\
\text { technology of }\end{array}$ & $\begin{array}{l}\text { Contracts for } \\
\text { the } \\
\text { development } \\
\text { or } \\
\text { production of } \\
\text { defense } \\
\text { equipment. } \\
\text { Contracts } \\
\text { related to R \& } \\
\text { D in the } \\
\text { defense } \\
\text { sector; }\end{array}$ & $\begin{array}{l}\text { Transfer of } \\
\text { technology } \\
\text { and know- } \\
\text { how; } \\
\text { cooperation / } \\
\text { collaboration } \\
\text { in technology } \\
\text { and R \& D; } \\
\text { purchase of } \\
\text { defense } \\
\text { products and } \\
\text { services; }\end{array}$ \\
\hline
\end{tabular}




\begin{tabular}{|l|l|l|l|l|l|l|}
\hline & $\begin{array}{l}\text { software; } \\
\text { technical } \\
\text { management, } \\
\text { production- } \\
\text { related and } \\
\text { integrated } \\
\text { logistics } \\
\text { support. }\end{array}$ & & & $\begin{array}{l}\text { interest from } \\
\text { the Ministry. }\end{array}$ & $\begin{array}{l}\text { Technology } \\
\text { transfer; } \\
\text { marketing } \\
\text { assistance. }\end{array}$ & $\begin{array}{l}\text { investments } \\
\text { that increase } \\
\text { the } \\
\text { competitiven } \\
\text { ess of the } \\
\text { defense } \\
\text { industry; } \\
\text { activities that } \\
\text { collaborate } \\
\text { for greater } \\
\text { access to } \\
\text { markets for } \\
\text { Swedish } \\
\text { products. }\end{array}$ \\
& & & & \\
\end{tabular}

\section{Source: Author's elaboration}

\section{Table 3}

Regarding the eligible sectors, it is verified that the central focus of the countries is the Defense area. Regarding the selection of receivers the process is at the discretion of the bidders, always following the previous requirements (example: requirements, objectives, etc). Monitoring is carried out by the responsible development agencies involved in the process.

Table 3 - Comparative Offset Policies - selected countries (part 3)

\begin{tabular}{|c|c|c|c|c|c|c|}
\hline & Canada & Spain & India & Italy & United Kingdom & Sweden \\
\hline $\begin{array}{l}\text { Eligible } \\
\text { Sectors }\end{array}$ & $\begin{array}{l}\text { It can be } \\
\text { targeted at all } \\
\text { high } \\
\text { technology } \\
\text { sectors: } \\
\text { defense, } \\
\text { aerospace, } \\
\text { automotive, } \\
\text { information } \\
\text { technology. }\end{array}$ & $\begin{array}{l}\text { Preference } \\
\text { for defence } \\
\text { or civil with } \\
\text { a suitable } \\
\text { dual-use } \\
\text { technology } \\
\text { content. }\end{array}$ & Defense & Defense & Defense & $\begin{array}{l}\text { Defense only } \\
\text { (since 2004) }\end{array}$ \\
\hline $\begin{array}{l}\text { Selection of } \\
\text { receivers }\end{array}$ & $\begin{array}{l}\text { Industry } \\
\text { Canada and } \\
\text { regional } \\
\text { development } \\
\text { agencies will } \\
\text { work with } \\
\text { bidders to } \\
\text { identify } \\
\text { potential } \\
\text { Canadian } \\
\text { companies. }\end{array}$ & $\begin{array}{l}\text { Bidders } \\
\text { have } \\
\text { complete } \\
\text { freedom to } \\
\text { choose } \\
\text { domestic } \\
\text { partners } \\
\text { and } \\
\text { suppliers. }\end{array}$ & $\begin{array}{l}\text { Bidders are } \\
\text { free to choose } \\
\text { the Indian } \\
\text { partner, } \\
\text { provided that } \\
\text { this partner } \\
\text { has not } \\
\text { previously } \\
\text { been barred } \\
\text { from doing } \\
\text { business with } \\
\text { the Ministry } \\
\text { of Defense. }\end{array}$ & $\begin{array}{l}\text { Bidders are } \\
\text { free to choose } \\
\text { partners in } \\
\text { the domestic } \\
\text { defense } \\
\text { industry. }\end{array}$ & $\begin{array}{l}\text { Bidders can } \\
\text { choose the UK } \\
\text { companies with } \\
\text { whom they will } \\
\text { establish offset } \\
\text { activities. }\end{array}$ & $\begin{array}{l}\text { The bidder is } \\
\text { expected to } \\
\text { select the } \\
\text { most cost- } \\
\text { effective } \\
\text { option when } \\
\text { choosing } \\
\text { Swedish } \\
\text { partners or } \\
\text { suppliers. }\end{array}$ \\
\hline Monitoring & $\begin{array}{l}\text { Annual } \\
\text { evaluation } \\
\text { conducted by } \\
\text { Industry } \\
\text { Canada of } \\
\text { contracts with } \\
\text { active offset } \\
\text { commitments }\end{array}$ & $\begin{array}{l}\text { Periodic } \\
\text { meetings } \\
\text { between } \\
\text { the bidder } \\
\text { and the } \\
\text { Industrial } \\
\text { Cooperation } \\
\text { Agency. }\end{array}$ & $\begin{array}{l}\text { Bidders are } \\
\text { required to } \\
\text { provide } \\
\text { semiannual } \\
\text { reports to } \\
\text { Defense } \\
\text { Offset } \\
\text { Management } \\
\text { Wing. }\end{array}$ & $\begin{array}{l}\text { Contractors } \\
\text { are required } \\
\text { to submit bi- } \\
\text { annual } \\
\text { progress } \\
\text { reports to the } \\
\text { MoD. }\end{array}$ & $\begin{array}{l}\text { They must } \\
\text { submit } \\
\text { semiannual } \\
\text { reports. }\end{array}$ & $\begin{array}{l}\text { Bidders are } \\
\text { required to } \\
\text { submit } \\
\text { annual } \\
\text { progress } \\
\text { reports. }\end{array}$ \\
\hline
\end{tabular}

Source: Author's elaboration 


\section{CONCLUSION}

Table 4 seeks to list the best practices, among those presented, by the selected countries. The variables listed are the same as those presented in Tables 1, 2 and 3. It is important to highlight that the selection of these "best practices" was based on criteria that sought to observe: 1) an interaction and penetration of the defense sector in the adoption of offset, 2 ) convergence of the compensatory policies with the local technological development from the relations between University / Research Institutes / local companies, 3) construction of policies based on syntonies between ministries and industrial and technological secretariats.

Table 4 - Best practices

\begin{tabular}{|c|c|c|}
\hline & Countries & Practices \\
\hline Legal base & United Kingdom & $\begin{array}{l}\text { Industry Participation Policy } \\
\text { (2003), revised in accordance } \\
\text { with the Industrial Defense } \\
\text { Strategy (2007). }\end{array}$ \\
\hline Responsible Authority & All quite similar & $\begin{array}{l}\text { Inter ministerial with special } \\
\text { focus on defense }\end{array}$ \\
\hline Goals & All quite similar & $\begin{array}{l}\text { Strengthen the Industrial } \\
\text { Defense Base }\end{array}$ \\
\hline Period of execution & All quite similar & Contract period \\
\hline Requirements & Sweden & $\begin{array}{l}\text { Minimum of } 100 \% \text { of the } \\
\text { contract value. Offsets are not } \\
\text { required from companies in } \\
\text { countries that do not have an } \\
\text { offset policy. }\end{array}$ \\
\hline Multipliers & Sweden & $\begin{array}{l}\text { They are usually not applied. } \\
\text { They can be considered for R } \\
\text { \& D unrelated to the contract, } \\
\text { which is developed in Sweden } \\
\text { for the participation of small } \\
\text { and medium-sized } \\
\text { enterprises, and in support of } \\
\text { priority areas for the Armed } \\
\text { Forces. }\end{array}$ \\
\hline Direct / indirect & All quite similar & Both categories are accepted. \\
\hline Eligible activities & Sweden & $\begin{array}{l}\text { Transfer of technology and } \\
\text { know-how; cooperation / } \\
\text { collaboration in technology } \\
\text { and R \& D; purchase of } \\
\text { defense products and services; } \\
\text { investments that increase the } \\
\text { competitiveness of the } \\
\text { defense industry; activities } \\
\text { that collaborate for greater } \\
\text { access to markets for Swedish } \\
\text { products. }\end{array}$ \\
\hline Eligible Sectors & All quite similar & Preferably Defense \\
\hline Selection of receivers & All quite similar & $\begin{array}{l}\text { At the discretion of the } \\
\text { bidders }\end{array}$ \\
\hline Monitoring & All quite similar & $\begin{array}{l}\text { Responsible development } \\
\text { agencies involved in the } \\
\text { process }\end{array}$ \\
\hline
\end{tabular}

Source: Author's elaboration

In spite of a strong similarity in the forms of action between the countries, it is possible to affirm that the "Swedish model" has a greater synergy with the criteria adopted for the selection of "best practices". It is in favor of this model that a strong interaction between small and medium-sized companies is sought, in convergence with the needs of the armed forces. 
This process seeks to deconcentrate the investments of large national groups and pulverize them in small and medium-sized technology-based companies. It also makes clear the importance of transferring technology and know-how to participating companies.

Some cases, such as India, make clear their strategic technological options for technology acquisition through offset. This type of policy option, to make explicit the support and the need to adopt support mechanisms for the defense sector, is very interesting once it makes clear to society the State's intentions with the adoption of mechanisms for the technological development of the Defense sector.

\section{References}

AGÊNCIA EUROPÉIA DE DEFESA (EDA) (2009). The_Code_of_Conduct_on_Offsets http:///docs/defaultsource/documents/The_Code_of_Conduct_on_Offsets.pdf (05 de novembro de 2013)

CHAGAS, Fernando Torquato (2004). “O offset no Exército Brasileiro” em: Warwar, Zuhair (org). Panorama da prática do Offset no Brasil. MRE, Brasília, Brasil.

Neuman, Stephanie (2010). "Power, Influence and Hierarchy: Defense Industries in a Unipolar World". Defence and Peace Economics, Vol. 21 , Issue 1, 2010.

SIPRI Yearbook 2004 (2008) Armaments, Disarmament and International Security. Oxford University Press, Oxford.

U. S. Department of Commerce (2012). Offsets in Defense Trade. Sixteenth Study. Bureau of Industry and Security. Disponível em http://www.bis.doc.gov/index.php/forms-documents/doc_view/396-offsets-in-defense-tradesixteenth-study

ABDI (2010). Base Industrial de Defesa. Estudos Setoriais

http://livroaberto.ibict.br/bitstream/1/549/1/Estudo_Setorial_Inovacao_Defesa.pdf.(05 de junho de 2013)

DAGNINO, Renato e CAMPOS FILHO, L. (2007). “Análise sobre a Viabilidade de Revitalização da Indústria de Defesa Brasileira”. Brazilian Business Review, Vol. 4, No.3, 2007.

SILVA, Darly Henriques (2007). “Cooperação internacional em ciência e tecnologia: oportunidades e riscos”. Revista Brasileira de Política Internacional, vol 50, n. 1, 2007. 